\title{
Erratum to: Synthesis and crystal structure of new heterocyles derived from saccharin and uracil carrying 1,2,4-oxadiazolylmethyl group
}

Yaşar Dürüst $^{1}$ • Besra Özer ${ }^{1}$ • Benson M. Kariuki ${ }^{2}$

Published online: 4 April 2015

(C) Springer International Publishing Switzerland 2015

\section{Erratum to: Mol Divers}

\section{DOI 10.1007/s11030-015-9577-3}

Unfortunately, the third author's surname was incorrectly published in the original publication. The correct name is given in this erratum.

The online version of the original article can be found under doi:10.1007/s11030-015-9577-3.

Yaşar Dürüst

yasardurust@ibu.edu.tr

1 Department of Chemistry, Abant İzzet Baysal University, 14280 Bolu, Turkey

2 School of Chemistry, Cardiff University, Cardiff, UK 